\title{
Chapter 8 \\ Kastom and theocracy: a reflection on governance from the uttermost part of the world
}

Jaap Timmer

Solomon Islands has the highest Constitution that was ever written in human history which is the Holy Bible and was inspired by God's Holy Spirit. It directs man to the way, the truth and the life. It is the inherent and immutable word of God the Almighty Creator. There is no man made constitution or declaration which can or will ever excel its literary works, saying, truths, promises and unchangeable prophetic message which are now being fulfilled in these last days (Solomon Star 2005).

As of 1998, it became apparent to the wider world that many Solomon Islanders were prepared to violently oppose the central governmentreacting to a long legacy of poor management of the country's resources. Honiara, Australia and the international media were alerted to what had gone wrong in Solomon Islands when long-standing tensions between people from Guadalcanal and Malaita sparked a violent campaign of forcible displacement of Malaitan 'settlers' from rural Guadalcanal and a subsequent backlash from Malaitan militants based mainly in Honiara. Thousands were affected by the 'tensions' and by skirmishes between opposing ethnic militias. A coup by Malaitan militants and renegade police officers in June 2000 resulted in the forcible removal of the incumbent Prime Minister, Bartholomew Ulufa'alu. Progressive deterioration in the economic and security situation culminated eventually in the intervention of the Australian-led Regional Assistance Mission to the Solomon Islands (RAMSI) in mid 2003.

The crisis did not, however, end with the arrival of RAMSI. The mission restored a level of law and order by disarming people, sentencing and 
imprisoning criminals, bringing to justice a number of corrupt government officials, providing some level of security to the national airport, policing the streets of Honiara and so on. Efforts were also put into recruiting and training new police and prison officers, training public servants and reforming government departments, but surprisingly little was done to address long-standing local concerns about the structure of the State. RAMSI seemed reluctant to address Solomon Islanders' long-standing aspirations for greater local autonomy and to tackle the intricacies of the devolution of power from Honiara.

When centralised government was introduced, colonial authorities acknowledged 'tribal links' by establishing four administrative districts and, after the Local Government Act in 1964, by allowing for the creation of local councils. As Corrin Care (2005:163-4) points out, however, the local councils were never set up properly. Plans for the devolution of power from Honiara to local chiefs were not implemented and regulations for the election of chiefs and governance of the functioning of the councils were never drawn up. People simply continued organising their communities and resources in ways they deemed appropriate - adapting to the changing circumstances that came with migration to the coast, the construction of roads, the introduction of coconut-tree plantations and the developing market for copra. At the same time, people began to think differently about leadership and gender relations as a result of Christian and state education.

After independence in 1978, a number of sometimes-conflicting statutes covering provincial government were passed (see Corrin Care 2005:163-4 for an overview). While these considered the role of traditional chiefs, they did not address the involvement of non-elected chiefs and elders. As a result, popular aspirations to involve local leaders or chiefs in government dating back to the colonial period were never accommodated.

As became clear during the violent uprisings during 1998-2002, grievances about the division of resources between the government in Honiara and the provinces constituted a critical focus of Solomon Islands politics. Despite the arrival of RAMSI, this grievance against national government control remains marked. The April 2006 riots in Honiara likewise gave vent to grievances against central government politicians and reflected perceptions that the government had failed to respond adequately to its citizens. In this chapter, I discuss one such localised popular reaction 
to central government control from the northern part of Malaita. The case also indicates that a general tendency among foreign observers to separate custom and Christianity precludes a good understanding of Solomon Islanders' perception of the State and its crisis.

The relevance of this chapter to the broader themes in this volume is the qualification it provides to overly static or romanticised conceptions of kastom and Christianity in current discussions about the challenges of governance in Solomon Islands and appropriate solutions. Analysts, policymakers, government and aid officials operating in Solomon Islands need to avoid depictions of kastom and Christianity as stable and conservative forces or, alternatively, as important for nation building. Kastom and Christianity are inherently dynamic world-views and, moreover, have come under considerable stress in recent times.

\section{Alternative constitutions}

Since independence, federalism — or the state government system, as it is popularly known - has been discussed regularly as an antidote to perceived over-centralisation. During the 1998-99 disturbances on Guadalcanal, indigenous militants demanded the establishment of a federal system, reacting against the dominance of Malaitans on their island and within the headquarters of the central government. Politicians from Western Province also strongly supported federalism (Kabutaulaka 2006).

A Constitutional Review Committee advocated the federalist option in 1987. As a federal republic, Solomon Islands would be a nation-state in which more power would be given to the proposed states than would coincide geographically with existing provinces. In this formula, particular importance was placed on establishing new financial arrangements, as the provinces felt that under the existing system control of resources remained concentrated among the small political élite in Honiara. The most contentious aspects of more recent proposals for federalism have been the allocation of revenue-raising capacity between the states and the federal government, the sharing of revenue between Honiara and the states and the fiscal equalisation between the states (Le Roy 2004:20).

What frustrates many people, in particular those living in rural areas, is that while there is constitutional recognition of customary land and 
resource ownership, practical arrangements do not deal adequately with conflicts over land and property. There is also a lack of guidance on how modern state laws should be applied in the local realm, where traditional rules are also under debate and revision. Many disputes arise from contested land rights. A source of enduring tension between landowners relates to plots of land with potential development value as sites for government or commercial ventures. This tension can result in conflict and is complicated further when some parties seek to apply state court rulings while others resort to traditional forms of resolution. The two approaches are, however, incommensurable as manifested in the recurring complaints heard in Solomon Islands (as in its neighbours) about the inappropriateness of modern law in a Melanesian context. These arguments are then extended to the incommensurability of the central state and Westminster model and indigenous systems of governance.

Some observers consider that poor governance and corruption in Honiara are a legacy of the British colonial government and failed attempts at giving more power to local chiefs. At the same time, there are immense practical challenges in determining who the chiefs are and how to organise communities with respect to modern issues relating to land tenure and the distribution of wealth from commercial enterprises. Nevertheless, there is a feeling that prosperity will come only if the government in Honiara changes its attitude, curtails corruption and gives the provinces a fair share of the wealth it controls. Consequently, any perceptions that officials in Honiara are engaged in dealings that are inconsistent with local norms about justice, and that are felt to disadvantage one's own region, are likely to generate considerable opposition in the region concerned.

This opposition is expressed in a variety of ways. First of all, there are the continuing demands for more autonomy in the provinces, in particular in Malaita. After the recent conflict, Malaita rejected the plan for a federal system of government discussed during the Townsville peace negotiations (Corrin Care 2005:167) and demanded its own executive governor and legislative assembly. Secondly, there have been violent attempts to change the current system of governance. The 1998-2002 conflict, as with the events in April 2006, represented, in part, instances of protest against powerful vested interests concentrated in the national capital and the marginalising effect these had on rural people. 
Among those with vested interests in the islands' resources are a number of Asian investors and businesspeople. It is no surprise that popular protest against corruption and unequal sharing of wealth is directed also at them. Moreover, Asian companies were believed widely to have increased their exploitation of Solomon Islands' natural wealth during and after the recent crisis (see Moore, this volume). People recognise that the principal Solomon Islands beneficiaries of this form of plunder are their own politicians. The outrage expressed in April 2006 was part of the tension intrinsic in growing economic disparities and the manifest failure of governance on the part of the Solomon Islands State.

In explaining these tensions and the resulting protests and outbreaks of violence, there is a common tendency among many outside observers to separate matters of church and religion from issues concerning state, society and governance. In practice, the meaning ascribed to kastom (custom) by Solomon Islanders and outsiders is often very different. To illustrate the differences, I will describe a religious movement in North Malaita that appears to offer a radical alternative to prevailing discourses about state-centred notions of governance. Although this is only one regional perspective out of many, it seeks to explain the particular concerns of many North Malaitans and the emotional dimensions of their experience of the modern state, Christianity and kastom.

Most explanations of the 'ethnic' conflict that broke out in 1998-99 offered by North Malaitans include references to the negative influence of introduced Western ways of government (in particular, the juridical system that clashes with customary ways), growing levels of individualism, unbridled criminal behaviour among élites and the progressive descent into a Babylonian apostasy, often taken as one of the many signs presaging the end of time. It is out of this broader experience of crisis and uncertainty that people often search for alternative ways of governing themselves and, in doing so, reflect on the power and usefulness of kastom. Some can even begin to revitalise traditions of relative freedom allegedly enjoyed in the past or promised in Christian lore in terms of redemption (see, for example, Lattas 1998).

In contrast with these indigenous explanations, those of outsiders stand rather sharply. Many of the external analyses of the Solomon Islands crisis have been offered by political scientists and historians and generally draw on accessible secondary sources, such as newspapers and Internet chat rooms. 
They seem to agree that improved governance in Solomon Islands requires fuller participation of rural groups or communities, communal leaders, civil society, women, churches and customary ways of doing things (Amnesty International 2004; Corrin Care 2005; Douglas 2003, 2005; Weir 2000).

In general, an idealisation of kastom in these outside views figures as a remedy for alienating state structures. Fraenkel (2004:187) notes that for many foreign observers kastom is identified as an authentic and thus desirable foundation. As such, kastom is also juxtaposed with the role of Christianity in processes of reconciliation and for rectifying the immoral behaviour of politicians. While Christian charity is seen as informing successful reconciliation after violent conflict, the restoration of kastom (devoid of Christian influences) is viewed as a socially appropriate way of restoring old balances. In contrast, many Solomon Islanders, in particular those of evangelical denomination, see Christianity and kastom as being inextricably linked (see, for example, Burt 1994; White 1991; Scott 2005). ${ }^{1}$

When looking at popular concerns and politics at the community level in Solomon Islands, kastom and Christianity are not merely layers of identity capable of uniting people, making them peaceful or otherwise serving as a foundation on which nationalism can be built. Rather, they are resources that are employed dynamically and creatively in people's everyday politics, whether to support peace or to exacerbate existing fault lines between ethnic and religious groups, and between national élites and rural communities.

\section{Kastom out of balance}

In the wake of the ethnic tensions in Solomon Islands, two books appeared that attempted to explain the conflict and its dynamics (Fraenkel 2004; Moore 2004). One of these authors, Clive Moore (2005), returned recently to the main arguments in his book Happy Isles in Crisis (2004) and, as well as providing an update, presented a critique of the Australian-led RAMSI.

While balanced at the level of political analysis, Moore provides a less satisfactory account of kastom. For example, when addressing the violence of the tensions, he suggested that there was disturbance to Solomon Islanders' 'cosmological balance' (Moore 2005:62). This cosmological balance comprises the complex symbolic links that people recognise 'between human relationships, lands, gardens, music, dance, everyday thoughts, speech, their 
ancestors and now Christianity' (Moore 2005:62). The configuration of activities and expressions is labelled generally as kastom.

The disturbance of kastom is what Moore sees as the root cause of the outbreak of violence during the crisis. He goes on to observe that these old balances are hard to accomplish because ' $[\mathrm{m}]$ alevolent spirits circulate in the winds, and constantly try to get in... RAMSI chased out the malevolent spirits, but this was hardly a cosmological solution. What is needed is a large-scale programme of restorative justice or transformative justice' (Moore 2005:62). This program is what Moore sees as customary, involving a complex knowledge of kinship and status and no final fixed adjudication. Only through this kastom program will the old balances be restored. The kind of kastom referred to implicitly here comprises kinship and social status and thus is not the kastom that is deemed important when people amalgamate or juxtapose kastom and Christianity. Consequently, Moore observes that '[t]oday's peace and reconciliation involved customary ways in combination with Christian faith and Western-educated leadership, but the old balances still need to be achieved' (Moore 2005:65).

Moore (2005) quotes Sinclair Dinnen's introduction in the latter's A Kind of Mending (2003), a volume on restorative justice practices in Melanesia, to substantiate his claim that kastom is an important foundation for a prosperous future for Solomon Islanders. Dinnen (2003:11-18), however, acknowledges that kastom is variable and dynamic, that when power changes so might kastom and that adaptation of local courts and restorative justice systems to kastom can itself become a source of injustice. This approach to kastom is in line with the view of most anthropologists and is also reflected nicely in the other book on the Solomon Islands crisis, Fraenkel's Manipulation of Custom (2004).

Fraenkel's account of the role of kastom in the ethnic conflict in Solomon Islands builds fruitfully on the extensive literature on the invention of tradition in the Pacific (see Otto and Pedersen 2005 for an overview). The author's methodology underlines explicitly the historical and cultural fact that 'introduced institutions have been thoroughly indigenised' (Fraenkel 2004:43, 185). Fraenkel (2004) notes that the juxtaposition between externally driven and indigenous influences continues to be prominent in the way Solomon Islanders understand the tension within their community, region and nation. 
The meanings of kastom that come to the fore in current discussions include: kastom as 'authentic and rooted' (and thus good); 'destructive' kastom, in the case of the permeation of the 'customary' wantok system (networks based on common linguistic or kinship bonds) into the bureaucracy; and kastom as 'powerful', evidencing that a local group relates to the roots of power and knowledge. In this last meaning, kastom relates to the particular kastom of one group and is seen as belonging authentically to that group. For that group, kastom underpins its rights, its access to resources and its identity in the local and wider world. This meaning of kastom is prominent in the religious movement discussed in this chapter.

Fraenkel focuses on kastom in relation to the compensation payments that played such a debilitating role in the Solomon Islands during the tensions of 1998-2003. He gives less prominence to the mobilising force of kastom as a basis for the assertion of indigenous rights and access to natural resources. Nevertheless, Fraenkel (2004:77) does acknowledge the growing sense of Malaitan difference and the urban anomie that is expressed increasingly in revived foundation myths, including the idea of the 'lost tribe of Israel'. These revived or, in some cases, invented foundation stories are themselves kastom and are part of long-standing local knowledge traditions, one of which I will detail below.

\section{Deep-sea canoe}

In this section, I discuss a religious movement among To' abaita speakers of North Malaita for which Christian lore provides the narrative and moral terms of reference. The connection that people see between Christian lore and kastom feeds a belief that serves to oppose mainstream churches and the government. This particular movement originated in the South Sea Evangelical Church (SSEC), established in 1966 out of the South Sea Evangelical Mission. The mission was brought back by Solomon Islanders from their 'blackbirding' experience in Bundaberg in Queensland, where they had worked on sugar plantations since the beginning of the previous century (Griffiths 1977; Hilliard 1960).

In early 1984, a group of elders of the SSEC was meeting to consider starting a new congregation in one of the suburbs of Honiara. During prayer time, one of the elders, Michael Maeliau, began to receive a vision from 
God.This typical end-time prophetic vision told the story of a massive wave that began in the Solomon Islands, travelled around the globe and ended up in Jerusalem (Hess 2003b:68-9; Maeliau 1998).

The vision begins with a valley that fills with crystal-clear (unpolluted) water, which develops into a flood and later becomes a cloud. The cloud travels to Australia and returns to Solomon Islands from where it goes to all the nations in the South Pacific. As the cloud reaches Papua New Guinea, it changes into a three-pronged powerful current that heads eastward towards the west coast of the United States. As it arrives in the United States, the central current continues towards the east coast then turns 180 degrees and develops into a mighty wave that eventually stretches from the North Pole to the South Pole.

The wave then rolls back and travels westward. The wave is so great that it submerges all the nations in its path and is so high that it floods even Mount Everest. It covers everything in its path as it moves over the Pacific and Asia until a circle encompassing the globe is complete. With the completion of the circle, the wave zooms in on Jerusalem and shoots up into the heavens like a mighty pillar. As it reaches high in the sky, it opens like a great mushroom that gradually spreads until it envelops the Earth. At this point, a voice comes from the cloud saying, 'And the Glory of the Lord shall cover the Earth as the waters cover the sea.'

A collection of stories about the spread of the gospel by South Pacific island missionary Alan Tippett (1994:9) explains that the term 'deep-sea canoe' relates to a Fijian and Tongan symbol for canoes that plied from island to island with trade goods, warriors and tribute. With the advent of Christianity in the region, the use of deep-sea canoes 'steadily shifted from the business of war and cannibalism to the transport of missionaries from one island to another' (Tippett 1994).

Peter Ambuofa, a local missionary, returned to North Malaita in 1894 to spread the gospel after two years' training in Bundaberg, Queensland (Hilliard 1960:45). The return of Ambuofa was seen by many as a great moment in Malaitan history, embodying simultaneous images of the past and the future. Official church history views his return as signifying an important turning point in the conversion of Malaitans from heathens to Christians. From that point onwards, the people of Malaita were expected to follow the line of becoming good Christians and modern Pacific islanders. Most followers of the Deep-Sea Canoe Movement, however, see the return of 
Ambuofa as an act of God to remind the people of Malaita of their unique role as inhabitants of 'the uttermost parts of the world'.

In the Sermon on the Mount (described in Matthew 5:7 and Luke 6:17-49; and see Acts 1:8), Jesus referred to the uttermost parts of the world as the geographical ends to which God's word should be spread. For most Christians in North Malaita, this is the most significant aspect of the sermon apart from its listing of codes of conduct or moral rules for social living. In the evangelical group of North Malaita who wish to prepare the world for the return of Jesus, the sermon is considered to replace the rules outlined in the thora (law). Only strict adherence to these rules will enable the restoration of Jerusalem and the eventual return of the Saviour.

The social and economic marginalisation of Solomon Islands-its (almost) 'uttermost distance' from Jerusalem - and the fact that people observe that the world around them is falling into apostasy, confirms their theory that Jesus had Solomon Islands in mind when He used the phrase 'the uttermost parts' in His Sermon on the Mount. Ambuofa is thus the key figure in the transformation of Malaita in the official and mainstream church narrative and in the widespread North Malaitan story about historical links between Malaita and Israel. In both stories, the Malaitan missionary brings about change, but in the latter the change is not from heathen to good Christians but involves the restoration of a temporarily discontinued link with the genesis of the world. Below I will explain the related Malaitan ideas about the promised land, the scattering of the people of the covenant and their present position in the Solomon Islands and in the world at large.

This particular interpretation of the Old Testament and the light it purports to shed on the origins of certain groups on the island of Malaita does not suggest that they are members of a lost tribe. Instead, they claim to be those people referred to in Jesus's Sermon on the Mount, who were the last and most distant group to receive the word of God. At the same time, however, people trace their ancestry back to figures in the Old Testament.

As indicated above, Michael Maeliau is a major figure behind the dissemination of and support for these beliefs. While many see him as a prophet, he also derives his status from his role in international evangelical networks. Regionally, he leads the Evangelical Fellowship of the South Pacific. $\mathrm{He}$ is also a member of the board of reference of the International Prayer Council, which believes it is compelled by God to seek Christ's glory world- 
wide for the blessing, healing and transformation of all nations (IPC n.d.). He is also affiliated with Tom Hess's Prayer Assembly movement (Hess 2003a).

Apart from his role in religious circles, Maeliau has also been active in national politics. In the mid 1990s, he was Minister of Home Affairs and in that capacity was responsible for approving a licence for the Honiara Casino (Alasia 1997:12), an act that appears to be inconsistent with his belief in a Godfearing community living according to God's commandments (see below). In 2006, he stood as an independent candidate for the elections for the national parliament. His program of reform promised a God-fearing and non-corrupt government, but his electoral campaign was ultimately unsuccessful.

In the religious sphere, he appears to have met with more success. In the past two decades, Maeliau's vision and movement has attracted a growing number of adherents, in particular from the SSEC churches in Nor th Malaita and Honiara. On the basis of interviews I have conducted with adherents and excommunicates of the Holiness Church, people's understanding of the deepsea canoe theology appears to be noticeably consistent. This theology is based largely on the dramatic events and laws detailed in the Old Testament.

The reason why some Malaitans adhere to old Jewish rules is that they consider themselves to be a covenant people with an ancestry going back to the biblical kings. Proof of this link with God's chosen people and an earlier movement of people from the Mediterranean to the Pacific stems from the belief that the Ark of the Covenant lies buried in the mountains of Malaita. When telling this story, people talk in similitudes. Thus, original Malaitan kastom (tradition) is viewed as the same as old Jewish forms of worship and specific proscriptions regulating social life.

In this sense, the core narrative of the Deep-Sea Canoe Movement is similar to that of the Remnant Church as described by Burt (1983). Visionaries among the Kwara'ae-speaking people who live near Auki, south of the To'abaita, founded the Remnant Church in the 1950s. The church was small and never attracted many more than 100 men and their families. To the present day, there are still only a handful of members. Adherents of the Remnant Church trace their ancestry to certain Old Testament migrations of the tribes of Israel and they remain committed to observing old Jewish religious laws.

Observers have identified parallels between kastom - understood as old practices of sacrifice to ancestors, ideas about traditional ritual pollution and laws for upholding good community living - and Christian ways. For 
example, Burt (1983:338) explains that 'theological parallels between the two religions have enabled Christian Kwara' ae to sustain some of the underlying premises of the pagan religion, which are reflected in the ideology of the Remnant Church'.

The Deep-Sea Canoe Movement and the Remnant Church position their theologies in the zone of friction between local ideas about kastom and the mainstream Christian teaching of the SSEC, the Roman Catholic Church, the Anglican Church and government. The local theology, or kastom, cannot be labelled simply as 'pre-Christian beliefs and practices' or 'traditional cosmology', as the people's interpretation of kastom is framed contingently in relation to Christian teachings and reflections on recent developments in the region.

In his analysis of the Remnant Church, Burt (1983:336) defines kastom as 'a set of values which Kwara'ae, like other Malaitans, regard as central to their traditional way of life, a perception reflecting the changes wrought or threatened by colonial domination'. When the seeds for the Remnant Church were sown originally by Zebulon Sisimia after an experience of possession by the Holy Spirit in 1955 in a broader context of mounting anti-colonial sentiment, much of the meaning of kastom had been recast in terms of a loss of sovereignty due to government control.

As Sisimia explained in a letter to Burt in 1981, his studies of the Bible showed him 'that the world had been ruled successively by the kingdoms of the Assyrians, Babylonians, Medo-Persians, Greece, the Romans and ten others to the present day, under three types of government; Monarchy, Oligarchy and Democracy. Sisimia saw that an alternative to these "tyrant" regimes of man was "Theocracy", the government of God given to Israel in the Old Testament' (Burt 1983:339). The Deep-Sea Canoe Movement follows this line of thinking while also expressing a deep-seated longing for autonomy and self-determination.

\section{Theocracy or the inversion of the nation}

Many people on Malaita are deeply concerned about the Holy Land and this is reflected in their changing interpretation and perception of the Scripture and their position in the region and larger world. The tradition of internalising biblical vocabulary_- 'uttermost part', 'promised land', 
'chosen people' and 'Jerusalem'-and applying it to visions of Malaita, To'abaita and Kwara'ae, evoke a powerful sense of ambivalence towards the modern state and its formal system of governance. Popular religious culture, in other words, is crucial to the construction of an oppositional political discourse in this part of the Pacific.

Many Malaitans claim that the Ark of the Covenant and the Temple of the Lord or Lost Temple of Jerusalem are buried at various locations in the mountains of Malaita. According to the Old Testament, the ark was placed in the holy of holies - the innermost room of the tabernacle. Those Malaitans who map features of the Holy Land onto their own territory say that the shrines for ancestor worship on the mountain tops in the interior of Malaita contain three sections. ${ }^{2}$ They call the most sacred and powerful section the holy of holies and they see the shrines as tabernacles. The innermost place was where ritual leaders offered pigs to the ancestors and where the remains of deceased leaders were buried.

Some claim that at these worship shrines, original Jewish worship to God was practised. Due to influences from outside, and, in particular, the introduction of cannibalism, these holy practices gradually disappeared. This happened between four and five generations after the first arrival of migrants from the Holy Land. As a result, people lost their memory of how to perform the appropriate rituals and, because of this, a generational conflict erupted. The generation that was supposed to follow in the footsteps of the ritual leaders was so diverted by the conduct of raids against others and severing the heads of enemies that they lost interest in the older practices that had originated in Israel. They shifted their belief in the powers of God to the powers of great ritual and war leaders. As a result, they began to make offerings to them and buried the bodies of their heroes in the innermost part of the shrine. Practices such as the offering of human flesh to ancestors aroused fierce reactions among elders and divided previously more or less united groups.

In light of this widespread deterioration in morals in present times, many people are reflecting deeply on what constitutes a God-fearing community. According to Deep-Sea Canoe theology, becoming holy is central to the restoration of the world to a previous divine order as narrated in the Old Testament. Mainstream churches and worldly governments are incapable of achieving this level of holiness. As a result, the Deep-Sea Canoe Movement 
seeks to overthrow the government and replace it with a theocracy that is executed by God-fearing leaders.

Moreover, the movement criticises mainstream churches, in particular the Roman Catholic and Anglican churches, for collaborating with the corrupt élites, mimicking Europeans and failing to acknowledge the spiritually founded sovereignty of Malaitans. ${ }^{3}$ So instead of bringing people together and uniting them to build a better future, the Deep-Sea Canoe Movement actively foments religious fault lines in society. In particular, tension between Jehovah's Witnesses and the Deep-Sea Canoe Movement is mounting. The Watchtower people (Jehovah's Witnesses) denounce strongly pagan practices and the idea of a return to old rituals is abhorrent to them, whether Jewish or otherwise. Another matter of concern to them is that the followers of the Deep-Sea Canoe Movement disassociate themselves completely from social contact with 'non-believers' or people who are considered not holy.

Central to my argument in this chapter is the contention that the Deep-Sea Canoe Movement's narrative of nation emphasises the limits of the modern state. Its explanation of Malaitan people's origin and the roots of their kastom and identity can be seen, at one level, as an inversion of the official Solomon Islands narrative of nation. In seeking holiness and claiming that it will play a central role in the reconstruction of the nation of Israel, the Deep-Sea Canoe Movement employs a powerful metaphor. In a situation in which most Solomon Islands political leaders describe their national character in terms of a Christian nation, the critique offered by the movement of mainstream Christianity and referred to regularly in nationalist rhetoric also turns the official version of Solomon Islands nationhood upside down and presents theocracy as the preferable alternative (cf. Collins 2004). ${ }^{4}$

\section{Conclusion}

In light of the themes of the current volume, one can conclude that the Deep-Sea Canoe Movement among To'abaita speakers on Malaita springs from people's deep-seated frustrations with decades of unfulfilled promises of development and the continuing deferral of the crystallisation of these promises (cf. Bennett 2002). Most Malaitans remain exceedingly sceptical about what a Westminster system of centralised government can offer them. 
As the movement shows, some among them have begun to actively redefine their sovereignty and individual aspirations in terms that depart markedly from the official language of post-conflict recovery and national progress.

Most Solomon Islanders are familiar with the modern rhetoric of progress. This rhetoric derives, in turn, from two main sources: the colonial and post-colonial government, and the churches. The government teaches about hard work, community development, good leadership and efficient infrastructure. Church teachings denigrate aspects of people's kastom such as ancestor worship, witchcraft, sorcery, primitive attire and so on, which are deemed to be heathen, shameful and belonging to the past, that is, to tradition or kastom. These two dimensions of modern reflection on the past come together in a variety of ways in ponderings on good governance.

At the same time, most Malaitans remain oriented strongly towards modern government. Despite their sustained criticism of present-day and colonial governments, the majority of rural people on Malaita seek connection with developments in Auki, Honiara and other parts of the world. As elsewhere in Solomon Islands, Malaitans have expressed strong demands for good health care, proper education and infrastructure that will facilitate economic and labour investment. Their aspirations for tangible progress are real and, as such, deserve recognition.

They share the concerns of many Solomon Islanders about a broad range of perceived threats to their individual lives, their communities and their country's future. These include growing individualism, declining morality, theft, corruption and 'money politics'. External observers have identified most of these as evidence of a weak or failing state. There is considerable consistency in people's identification of these threats, although there remain significant differences in perceptions about how they should or can be overcome.

Generally speaking, people in Malaita see threats to their well-being issuing from the predominance of Western ways of doing things and the related decline of customary ways (as defined nostalgically in response to the perceived threat), while many also see that as God's plan for humankind. The latter interpretation is most prevalent among evangelical Christians and is fed continuously by those who see signs of the end-time, thereby linking the Revelation to St John to events around them.

The Deep-Sea Canoe Movement reflects a widespread concern among North Malaitans with topology and the related moral foundations of society. 
It is through connections with markers in their immediate landscape - the territory that belongs to one's kin group - that rural people articulate their position in the world and the pride and fame of their particular group. As the significance of the landscape changes, with land becoming an increasingly commoditised economic asset, the mapping of kin-group histories and their rights to land and wealth contained in or on the ground becomes ever more critical and people also accept new customary rules to regulate land rights.

The meaning of kastom in North Malaita is shaped in relation to the evergrowing divide between the élites in Honiara and Auki (including 'the Asians'). The case discussed in this chapter underscores the point that understanding the people of North Malaita entails not only documenting and analysing their past (or kastom) and their Christian beliefs, it involves acknowledging that these people respond in very particular ways to colonialism, the postcolonial state and long-delayed promises of development.

\section{Acknowledgments}

Fieldwork for this paper was undertaken between December 2005 and March 2006, with the permission of the Ministry of Education, the Ministry of Foreign Affairs and chiefs in North Malaita. I am grateful particularly to George Hoa'au, David Suata, Adam Ulufa'alu, Francis Iro, Steward, Lawrence Luiramo, Peter Kwanairara, Frank Daifa and Terry Brown. I thank Sinclair Dinnen for his valuable comments.

\section{Notes}

1 For a general discussion on the use of Christianity in people's empowering of the past in Melanesia, see Strathern and Stewart 2004:Ch.8.

2 See Burt and Kwa'ioloa (2001:29) for a drawn plan of such a shrine at Siale, on Kwara'ae land.

3 Similarly, Sabbath-keeping Anglicans oppose the mainstream Anglican Church in the Kwara'ae region. According to the Anglican Bishop of Malaita, Terry Brown, the Sabbath-keeping Anglicans form a direct line with the Remnant Church. Recently, the group burned the altar in the historical Anglican church in Fiu (Brown 2004:8-15).

4 Most recently, the Chief Justice of Solomon Islands, Albert R. Palmer, reflected on failed leadership in his country and noted that 'God has given this nation another chance to do it right' (Palmer 2005:4). 


\section{References}

Alasia, S., 1997. Party politics and government in Solomon Islands, Discussion Paper 97/7, State, Society and Governance in Melanesia Program, Research School of Pacific and Asian Studies, The Australian National University, Canberra.

Amnesty International, 2004. Solomon Islands: women confronting violence, 8 November. Available from http://web.amnesty.org/library/pdf/ ASA430012004ENGLISH/ \$File/ASA4300104.pdf (accessed 17 June 2006).

Bennett, J.A., 2002. Roots of the conflict in Solomon Islands. Though much is taken, much abides: legacies of tradition and colonialism, Discussion Paper 2002/5, State, Society and Governance in Melanesia Program, Research School of Pacific and Asian Studies, The Australian National University, Canberra.

Brown,T., 2004. Christian contextual theology: a Pacific example-Malaita's Sabbath-keeping Anglicans and the hermeneutic circle, Keynote address to conference on Contextual Theology in the Pacific, Bishop Patteson Theological College, Kohimarama, Solomon Islands, 22-25 August.

Burt, B. and Kwa'ioloa, M. 2001. A Solomon Islands Chronicle, as told by Samuel Alasa'a, British Museum Press, London.

Burt, B., 1983. 'The Remnant Church: a Christian sect of the Solomon Islands', Oceania, 53(4):334-46.

- 1994. Tradition and Christianity: the colonial transformation of a Solomon Islands society, Harwood Academic Publishers, Chur.

Clark, J., 1997. 'Imagining the state, or tribalism and the arts of memory in the Highlands of Papua New Guinea', in T. Otto and N. Thomas (eds), Narratives of Nation in the South Pacific, Harwood Academic Publishers, Amsterdam:65-90.

Collins, J.F., 2004. “'X marks the future of Brazil”: protestant ethics and bedeviling mixtures in a Brazilian cultural heritage center', in A. Shryock (ed.), Off Stage/On Display: intimacy and ethnography in the age of public culture, Stanford University Press, Stanford:191-222.

Corrin Care, J.C., 2005. 'The search for a more appropriate form of government in Solomon Islands', in B.A. Hocking (ed.), Unfinished Constitutional Business? Rethinking Indigenous Self-determination, Aboriginal Studies Press, Canberra:159-69. 
Dinnen, S., 2003. 'Restorative justice in the Pacific Islands: an introduction', in S. Dinnen with A. Jowitt andT. Newton Cain (eds), A Kind of Mending Restorative Justice in the Pacific Islands, Pandanus Books, The Australian National University, Canberra:1-34.

Douglas, B. (ed.), 2003. 'Women's groups and everyday modernity in Melanesia', Oceania, 74(1-2), Special issue.

Douglas, B., 2005. Christian custom and the Church as structure in 'weak states' in Melanesia, Paper presented at the Civil Society, Religion and Global Governance: paradigms of power and persuasion international conference, Canberra, 1-2 September.

Fraenkel, J., 2004. The Manipulation of Custom:from uprising to intervention in the Solomon Islands, Victoria University Press, Wellington.

Griffiths, A., 1977. Fire in the Islands! The acts of the Holy Spirit in the Solomons, Harold Shaw, Wheaton, Illinois.

Hilliard, D., 1960. 'The South Sea Evangelical Mission in the Solomon Islands: the foundation years', Journal of Pacific History, 4:41-64.

Herzfeld, M., 2005. Cultural Intimacy: social poetics in the nation-state, Second Edition, Routledge, New York and London.

Hess, T., 2003a. God's Abrahamic Covenants with Israel_Biblical Road Map of Reconciliation: restoring the altars, foundations, and pillars - the mountains of Israel, Progressive Vision International, Jerusalem.

— 2003b. Sons of Abraham: worshipping God together as a blessing on the Earth, Progressive Vision International, Jerusalem.

International Prayer Council (IPC), n.d. http://www.ipcprayer.org/ mission.html

Kabutaulaka, T.T., 2006. 'Melanesia in review_issues and events 2005: Solomon Islands', The Contemporary Pacific, 18(2):423-30.

Keesing, R., 1992. Custom and Confrontation: the Kwaio struggle for cultural autonomy, University of Chicago Press, Chicago and London.

Lattas, A., 1998. Cultures of Secrecy: reinventing race in bush Kaliai cargo cults, University of Wisconsin Press, Madison.

Le Roy, K., 2004. Comparative constitutionalism: establishing legitimacy and understanding the options of federalism, Discussion Paper, based on a presentation made at the University of the South Pacific, Suva, 15 November. 
Maeliau, M., 1987. 'Searching for a Melanesian way of worship', in G.W. Trompf (ed.), Black Theologies from the South Pacific, Orbis Books, Maryknoll, New York:119-27.

_ 1998. The Deep-Sea Canoe Vision, End Time Prophetic Vision. Available from http://www.etpv.org/1998/seacanoe.html (accessed 19 June 2006).

Moore, C., 2004. Happy Isles in Crisis: the historical causes for a failing state in Solomon Islands, 1998-2004, Asia Pacific Press, The Australian National University, Canberra.

— 2005. 'The RAMSI intervention in the Solomon Islands crisis', The Journal of Pacific Studies, 28(1):56-77.

Otto, T. and Pedersen, P., 2005. 'Disentangling traditions: culture, agency and power', in T. Otto and P. Pedersen (eds), Tradition and Agency:tracing cultural continuity and invention, Aarhus University Press, Aarhus:1149.

Palmer, A.R., 2005. 'Foreword', in K.F. Sanga and K.D. Walker, Apem Moa: Solomon Islands leadership, He Parekerekere, Institute for Research and Development in Maori and Pacific Education, Victoria University, Wellington:3-4.

Robbins, J., 2005. 'The humiliations of sin: Christianity and the modernization of the subject among the Urapmin', in J. Robbins and H.Wardlow (eds), The Making of Global and Local Modernities in Melanesia: humiliation, transformation and the nature of cultural change, Ashgate, Hampshire:43-56.

Scott, M., 2005. "I Was Like Abraham”: notes on the anthropology of Christianity from the Solomon Islands', Ethnos, 70(1):101-25.

Solomon Star, 2005. 'An observer', Solomon Star, 22 February.

Strathern, A. and Stewart, P.J., 2004. Empowering the Past, Confronting the Future: the Duna people of Papua New Guinea, Palgrave Macmillan, New York.

Tippett, Alan R., 1994. The Deep-Sea Canoe: Stories of the Spread of the Gospel by South Pacific Island Missionaries, Christian Books Melanesia, Wewak.

Weir, C., 2000. 'The churches in Solomon Islands and Fiji: responses to the crises of 2000', Development Bulletin, 53:49-52.

White, G.M., 1991. Identity through history: living stories in a Solomon Islands society, Cambridge Studies in Social and Cultural Anthropology, 83, Cambridge University Press, Cambridge. 